\title{
ADVANCES IN INFORMATION SCIENCE
}

\section{Evolving academic library specialties}

Andrew M. Cox (corresponding author)

Lecturer, The Information School, University of Sheffield, Portobello, Sheffield S1 4DP

a.m.cox@sheffield.ac.uk

Sheila Corrall

Professor and Chair, Library and Information Science Program, School of Information Sciences, University of Pittsburgh, 605C Information Sciences Building, 135 North Bellefield Avenue, Pittsburgh, PA 15260

scorrall@pitt.edu

The purpose of this review is to examine the shaping of librarianship in the academic context through the literature of career specialties, with Abbott's (1988) system of professions providing an analytic framework. The specialties investigated are systems librarian, electronic resource librarian, digital librarian, institutional repository manager, clinical librarian and informationist, digital curator/research data manager, teaching librarian/information literacy educator and information and knowledge manager. Piecemeal literature based on job advertisements, surveys and individual case studies is consolidated to offer a novel perspective on the evolution of the profession. The resilience of the profession's core jurisdiction is apparent despite pressures to erode it. Forays into teaching and more recently into open access and data management can be understood as responses to such pressure. The attractions but also the risks of embedded roles and over extended claims become apparent comparing past and prospective specialties.

Academic librarianship, specialties, careers

\section{Introduction and scope}

The literature of academic library work has strands of optimism and pessimism. Currently optimism centres around potential roles in the management of research data. This is claimed to be a natural extension of the library's place in the support of scholarship, but might take librarians into specialties embedded in academic departments and research teams. Yet this hope echoes past optimism around the role of librarians in Knowledge Management (KM) , which has largely been disappointed. Longstanding fears that core activities of libraries will be swept away by technology were brought to a head in the UK by a proposal at Bangor University to dispense with subject librarians altogether (Jones-Evans, 2005). In concrete terms the economic downturn since 2008 has led to reduced staffing levels in libraries (Nicholas, Rowlands, Jubb \& Jamali, 2010). One of the preoccupations of library and information science (LIS) and its literature is the profession's own status and future, yet it is hard to grasp the overall pattern of change. 
The opportunities for new applications and extensions of professional knowledge in an information society are balanced by threats from managerial power, changing technologies, funding priorities and rival professional and disciplinary visions. How academic libraries as one of the heartlands of librarianship are reshaped by these forces will have a large impact on the direction of the whole profession. There are several ways this could be explored, but one feature of changing times in academic librarianship has been the emergence of new specialties. These range from the systems librarian or digital librarian to the institutional repository manager and now the research data manager; there are also the information literacy educator, the informationist and the information or digital asset manager. This paper reviews such developments as described in the literature over the last two decades. It seeks to characterize how new academic library specialties have developed and then to map patterns to produce a bigger picture of the development of academic librarianship as a whole.

The academic sector has been chosen as a focus partly because there is a significant body of literature available for review. The same exercise would not be possible with other sectors because a similar mass of literature does not exist. Yet even the academic literature is often piecemeal: focusing on particular new specialities, usually in one country at one time. Relatively few studies have employed multiple methods to triangulate findings from different sources of data or conducted longitudinal investigations of how things change over time. The vivid snapshots the literature provides are rarely linked together or analyzed theoretically. To some degree these issues can be addressed through a wide ranging review. We believe this is the first survey of the evolution of librarianship from a career specialties perspective. Reviewing the literature as a whole allows us to evaluate the quality of the evidence authors have collected. Also, by bringing together a fragmented literature, within a stronger theoretical framework, it may be possible to provide a clearer understanding of the forces shaping how academic library work is developing. Identifying common patterns, such as recurrent drivers, will give us insights into how future specialties could evolve and help us to understand how to influence events positively.

The first part of the paper outlines Andrew Abbott's (1988) theory of the system of professions as the chosen theoretical framework for the analysis of the literature; the second part weighs up the literature as a whole, with particular reference to the strengths and weaknesses of the different types of research that have been published, and the research methods they employ; the third part presents case studies of eight new specialties in the field; and the fourth develops an overview, represented as a jurisdictional map of academic librarianship, using Abbott's system of professions as the basis of the analysis.

\section{The system of professions}

In the increasingly complex occupational structure created by industrialism, some middle class occupations sought professionalization, representing autonomy from bureaucratic coordination and social cohesion around service as a refuge from social anomie (Winter, 1988). In the mid C20th sociology took a rather unquestioning view of the special social value of professions and focussed on discovering the "traits" that enabled occupations to achieve professional organization. Such traits included: a knowledge base, autonomy, an association, a code of ethics and values, and high economic rewards and social status. In this tradition librarianship was sometimes classified as a "sub-profession" because it was a less cohesive, homogenous and powerful group (Goode, 1969). In the 1970 s and ' 80 s a growing critique of professions as institutions in society (Freidson, 1994) was 
reflected in more critical theoretical views of the professional project as a drive to achieve status and reward for social elites, in the work of authors such as Larson, Witz, and Abbott. Earlier concepts of the profession were also seen to be over reliant on a few historically contingent models. Indeed, outside the USA and UK, occupations developed differently and the sociology of professions is therefore rather different, with more focus on the role of the state (Evetts, Gadea, Sánchez \& Sáez, 2009).

Gorman and Sandefur (2011) argue that mainstream sociological theorisation of the profession as such stalled after the 1980s, because of a number of changes to the conditions of professional work. Interest has fragmented, they argue, but in directions where the continuity with "traits" can be discerned, such as in studies of the nature of expert knowledge, responses to declining autonomy, decaying ethical consensus and inequality among knowledge workers. Also pointing to a large number of profound changes in the context of professional work, Burns (2007) identifies a need for a "post-professional" approach to studying professions, offering a different list of foci of study. The notion of a profession remains an important concept both as a reference point in the real world for professionalizing groups and for analysts of occupation. Among theorists Abbott (1988) remains influential.

Abbott's (1988) The system of professions has been influential both in the general understanding of the professions and specifically in the library literature (e.g. Danner, 1998; O'Connor, 2008, 2009; Ray, 2001; van House \& Sutton, 1996). Abbott himself has written about the information professions in North America $(1988,1998)$. Abbott's work examines the historical evolution of occupational groups. He regards professionalization not as a once and for all progression of an occupation, but rather investigates it as a complex and contingent historical process, in which groups claim status and closure, but where success is continuously reshaped by struggle with adjacent professions, and by wider social changes. An occupation is organized around the perpetually changing work it carries out; how work is controlled and how this changes is key to its fate. Wider forces, such as social and cultural change, shape the path of occupations, and so his analyses are broad historical sketches.

For Abbott, two key trends shaping occupational organization in the $20^{\text {th }}$ century were technology and the rise of organizations as ways of ordering expertise in competition with professionalization. Expertise can be "commodified" in technologies rather than professions - but Abbott argues that technology more often creates work for them. Expertise can also be located in organizations, controlled by managers. The strategy of professionalization implies an occupational group's autonomy; in contrast, Evetts (2003) points to the emergence of a generalized discourse of organizational professionalism, which is used "from above" by managers to discipline all workers and set standards of service.

Abbott shares with other scholars of occupations an interest in internally driven change in work and in the internal structuring of occupations, an analysis developed for librarianships fully by Winter (1988). Abbott is also interested in the way subgroups struggle with each other to define the profession. The social structure of a profession is seen as an autonomous variable, so that how it organizes itself can affect whether it is good at competing with other professional groups, and how it competes. Even more important than this internal perspective, and central to Abbott's view of professions, is the way that an occupation's experience is shaped by competition between adjacent professions for "jurisdiction", i.e. exclusive control over areas of work. Competition for jurisdiction 
occurs in the legal sphere, public opinion and the workplace. Different types of settlement of jurisdiction are possible: for example, one group can become subordinated to another. Witz's (1992) work points to the gendered nature of the professional system, and the way that women's work is often segregated and subordinated.

It may be that Abbott's preoccupation with competition is a peculiarity of a theory developed in the 1980s. From his perspective, talk of collaboration is usually interpreted as masking claims to compete for jurisdiction (Ray, 2001; O'Connor, 2008). However, the ideology of modern organizations has changed since the time he was writing. His theory does recognize that jurisdiction over work can also be split between two occupations. In addition, Abbott recognizes that at the workplace level, much "assimilation" of the tasks of adjacent occupations takes place, but he regards these as vulnerable positions; they tend to be viewed suspiciously from the point of view of the professionalization project of the occupation. Since the shift in organizational culture towards discourses of collaboration, partnership and co-opetition (Nalebuff \& Brandenburger, 1997) seem very significant, the survival of the fittest feel to Abbott's work may be of less applicability than in earlier decades.

Abbott's work does, however, provide a powerful framework for reflecting on change in the professional space of LIS. Abbott characterizes librarianship as a "federated profession", a loose collection of occupational subgroups doing rather different work, but with a "common orientation" (1998, p. 41). This character makes the occupation unlikely to achieve full closure, where there is a legal requirement to be a certified professional in order to practice, but does enable it to be very responsive to change. For Abbott, during most of the $20^{\text {th }}$ century the access jurisdiction, the "physical custody of cultural capital," (1988, p.217) was very much the dominant jurisdiction of librarianship; a stable claim where there were no competitors. The focus on access arose from the early domination of the profession in North America internally by academic and research libraries, because of the social prestige associated with their institutions and the strength of their networks based on resource sharing. This was further combined with the relative failure of the educational (i.e. teaching) jurisdiction of the profession in this particular context, because academics were perceived as greater experts on the contents of collections than librarians.

Yet within the Abbottonian analysis the access focus could prove to be a long term vulnerability because the public image of a profession is slow to change; therefore, if it comes under threat, it is difficult for the profession to adjust and disconnect itself from images of the physical library. A crisis for the access jurisdiction as physical library/books has been the threat from technology and also government cuts and increasing managerialism. O'Connor (2008) locates a critical period in the 1980 s and the response that preoccupies her is the reinvigoration and reinvention in the 1980s of the educational role, as a core life skill, different from sheer literacy or information technology (IT) literacy. However, the process is ongoing and can be traced through all the academic library specialties under review here.

\section{The character of the literature}

The dominant research methods in use in the literature about new specialties are:

- Content analysis of job advertisements

- Surveys of current practitioners 
- Case studies of individual institutions or thought pieces written from general knowledge of a sector of work.

Content analysis of job advertisements

Content analysis of job advertisements or postings is probably the commonest method in use to study trends in library work. One of the strengths of this approach is that such announcements potentially provide sector-wide longitudinal data, permitting the researcher to track the growth of a role over a long period. In reality, not many individual studies actually analyze changes over time in any depth. The data are detailed. Some authors have made much of the difference between required and preferred competencies as a way of uncovering common priorities (e.g. Choi \& Rasmussen, 2009; Sutton, 2011). Another appeal of this source of data is that it is published and so takes little effort to collect. Engel and Robins (2008, p. 114) express fears about the threat to long term access to data about career developments arising from the rise of online advertising and the tendency for printed advertisements to be "skeletons" without a full job description, which is offered on application. However, as Sutton's (2011) use of the Internet Archive demonstrates, full details of jobs can often be recovered. Online announcements make getting text for analysis easier and encourage researchers to broaden the scope of the advertisements included beyond a single publication, to be more comprehensive, and also to make more international comparisons.

Nevertheless, there are at least two important types of problems with this genre of research, one relating to the nature of the data and the other to the use of the data. Firstly, job advertisements do not necessarily give a clear indication of the true requirement or what people employed as a result of the advertisement actually do. Particularly in dynamic areas where the requirements of a role are as yet hazy (e.g. in the KM field), those designing position announcements may not successfully identify what is needed (Snyman, 2001). To treat them simply as transparent indicators of the requirements is simplistic; for example, some studies of job advertisements interpret them as about developing the brand of the employer (Backhaus, 2004).

As well as these problems with the data, the second issue is that the rigor of many such studies is somewhat questionable. Researchers rarely provide evidence of the robustness of categories through tests of inter-coder reliability. Much of the clustering of competencies involves a high degree of interpretation. This is inevitable since job advertisements do not use a standardized vocabulary, and while we may accept the researchers' competence to make such interpretations, it also reduces comparability when each study builds up its own set of categories from the data. Many published studies fail to use tests to evaluate whether the patterns seemingly present in the data are statistically significant.

Surveys of current practitioners

Another common approach to studying new specialties is to conduct a survey, usually via questionnaire, and often distributed via relevant discussion lists. The strength of this approach relative to job advertisements is that it is more likely to be accurate about what people actually do, rather than the potentially idealized or incomplete requirements appearing in recruitment advertisements. Data can be collected about a range of questions such as time in the profession, age, gender, or ethnicity. Opinions can be canvassed about what are the most important current issues. The number of questions asked can be expanded, but the source data are less frequently available in a convenient already-published form. 
Again, there are some problems with such studies, both with the data and how they are typically used. A survey is a snapshot of practice or opinion. Unfortunately, such surveys are rarely repeated over a number of years. The respondents are self-selecting and it is hard to evaluate whether the responding sample fully reflects the actual population. Generally studies are done through one discussion list, and probably do not provide material for international comparison. The closed questions in questionnaires have to be carefully designed and there is not always evidence that the survey instrument has been piloted. As with advertisement-based studies, statistical testing for significance of results is relatively rare. The full questionnaire and response data are not always published.

Individual case studies and personal accounts

Although individual case studies, based on personal experience of carrying forward a new role can be seen as largely anecdotal, they do give a lot of detail and a sense of the feel of a new practice, not captured in job advertisements or surveys, in a context where there tends to be a lack of more systematic in-depth qualitative studies. Inevitably, there is a bias towards innovative cases and often towards the larger institutions' experience. Such accounts often contain informed speculation about the future of the role and anticipate the impact of change long before it has fully worked itself out in most workplaces. The individual case study provides an essential third point of triangulation for the

study of new specialties in the information field. They are probably to be preferred to what might be termed pure advocacy pieces, where the basis for speculations about what is required is really derived from theory, or informal sources that cannot be checked. But even these have some value, because they can be based on experience and extensive if unsystematic discussions within professional communities, and also may have actually had direct influence on thought within the profession.

Methods summary

Much of the research in this field has been driven by educators' concern to adjust curricula to emerging job markets, so that typically studies focus on new specialities at the moment of reaching a level of critical mass, rather than at a stage of recognized full maturity. Longer term developments are less systematically studied. The case study literature is probably biased towards bigger institutions, e.g. case studies are likely to be written by professionals in larger wealthier institutions where specialities emerge earlier and more strongly, because the division of labour is more developed. However, this does mean that likely future developments are identified and understood very early.

The scientific rigor of many of the studies reviewed here is not high, or at least is unclear. But given that most studies have been done either by practitioners in a new area, curious about how others are coping with a new role, or by LIS educators, the authors bring much tacit knowledge and informal understanding to their research. Indeed the literature published has probably actively influenced how those defining new roles have designed actual job descriptions.

With some exceptions, the literature in this field consists typically of one-off studies, in one specialist area, using one form of data (e.g. job advertisements analysis or an online survey) and based on data from a single country, most often the USA and Canada. Thus findings are not triangulated with multiple sources of data within individual studies and significant international differences in the shape of the profession are rarely captured. The more novel the specialism, the more rapidly it 
evolves, the more difficult it is to achieve comparability, precisely because existing competency frameworks, such as those of the American Library Association (ALA, 2009) and Special Libraries Association (Abels, Jones, Latham, Magnoni \& Marshall, 2003) are too broad or do not cover the latest skill sets. Further, most individual studies have not been designed to facilitate future close comparison, e.g. they do not use generic frameworks of competencies as reference points and generally pursue specific questions relevant to that speciality. The value of the present review lies largely in addressing these problems of fragmentation. Collectively for each speciality and across the whole field the literature does offer us a convincing picture of how academic librarianship is developing.

\section{The specialities}

There are a number of ways the discussion of the specialities could have been ordered, e.g. chronologically. Abbott's theory focuses on jurisdictional contestation, so the logic of ordering here reflects how different specialities relate to adjacent professions. We begin with the specialities that relate to the evolution of the historically strong "access jurisdiction" of librarianship, namely systems librarian, e-resource librarian, and digital librarian. We then consider the roles that impinge on the research side of the faculty member: namely, the repository manager, the informationist, and the data manager. The third area relates to the educational jurisdiction, where the teaching librarian/ information literacy educator can be understood to lie. We conclude by looking at the relation with administration, through roles in information management (IM) and KM.

Systems librarians

The role of systems librarian and the systems team originated in the emergence in the 1970s of what is now described as the Integrated Library System (ILS) (Lavagnino, 1997) and is often seen as defined by being the essential and niche role of being a "broker" (Barley, 1996) between the library as an organization and a third party ILS supplier (Rhyno, 2003). As the use of IT in libraries has broadened the role has at least temporarily expanded to the management of all IT used in the library (Jordan, 2003).

Lavagnino (1997) proposes four stages of evolution for the systems role. The first stage is before computerization. The second stage sees the arrival of mainframe library systems. The third stage comes with the arrival of the ILS. For Lavagnino the key driver for the fourth stage is networking and the move to a distributed, client-server computing environment. This fourth stage sees four specific types of change in the systems role, namely more technologies to manage, more need to collaborate, the creation of a systems team (so that the systems librarian becomes a manager), and more direct services to users. It is not clear all the consequences of stage four have yet been realized in all libraries, perhaps partly because the causal linkage to technology as a driver implied by Lavagnino is simplistic and because the technological changes have been different and more far reaching in their consequences than were apparent when she was writing, enough perhaps to talk of a fifth stage of evolution. The move of all systems onto the web has meant that systems librarians have to deal with a proliferating number of technologies, where the challenge is integration, but they are not specialist systems like ILS, rather generic web-based ones (Rhyno, 2003).

Whereas Lavagnino (1997) construes the evolution of the systems role as an upward path, other commentators draw out some of the more double edged nature of the changes at work. If the security of the role has been built on the relationship with the systems supplier (Rhyno, 2003), the 
proliferation of web-based technologies implies an onerous need to have a working knowledge of many different systems (Pfohl \& Hayes, 2001). The high status role of the brokering relationship with the ILS supplier can often descend into the low status work of "buffering" (Barley, 1996) between users and technologies that break down (Seadle, 2003). Confirming one of Lavagnino's (1997) features of stage four, Guinea (2003) sees the systems librarian as a "mediator" and "bridge", not just with the systems supplier, but also within the library and between the library and computer/technology services. But often computing professionals themselves see systems librarians as "quasi-amateurs: more like power-users" (Seadle, 2003, p. 267).

As the importance of technologies has grown, Lavagnino (1997) suggests the role moves out of technical services to become a new department reporting to the head of service; it has a team of specialists (probably without library backgrounds (Lim, 2007)) and the systems librarian evolves into a manager and generalist. Nevertheless, Igelesias's (2010) statistics suggest that most teams are still of three or under. Indeed his survey found that only $45 \%$ of systems librarians were in their own department, which means many libraries still may not have reached Lavagnino's (1997) fourth stage. Lim's $(2007,2008)$ studies have revealed the only moderate job satisfaction, sense of belonging and autonomy among systems team members.

In the long run the trend to enterprise computing implies fewer specialist systems managed locally in the library (Breeding, 2009). Trends also point towards the replacing of a single ILS supplier with multiple systems and services hosted in the cloud. So long as there are books to circulate one may need an ILS; but as the centrality of book circulation is eclipsed, so the mission critical nature of ILS will decline. Clearly this would have consequences for the role and status of systems librarian. The possibility of more intense resource sharing (SCONUL, 2009) reinforces the tendency toward working collaboratively identified by Lavagnino (1997), but again could be seen as reshaping the systems librarian role in fundamental ways.

Xu and Chen's $(1999,2000,2001)$ studies, although now a little old, are the most systematic data on the character of systems librarian roles, based on analysis of job advertisements and a survey. Their studies seem to confirm the move into management. Management roles of planning, developing and purchasing were reported as frequent activities, even though the latter was rarely mentioned in job advertisements. Maintaining and supporting systems and to a much lesser extent programming were mentioned. Thompson (2009) develops the significance of distinctions between managing, maintaining and developing/customizing systems, since the three imply different postures towards the technology. On the human side, in Xu and Chen's studies, perhaps surprisingly, training came out as the most frequently mentioned activity, with co-ordinating and supervising. The wide range of technical knowledge required was confirmed. Thompson (2009) gives a more up-to-date discussion of the relevant technologies. Library specific knowledge was primarily around knowledge organization. Interpersonal, communication, analytic and organizational skills were all universally seen as needed, though rarely mentioned in job announcements.

Electronic resources librarians

The increasing use of the web to offer publishers' databases, full-text journals and in the 2010s ebook material has created roles selecting, organizing and supporting access to libraries' licensed (and free) electronic content. Attempts to manage access via cataloguing in the online public access catalog (OPAC) proved too complex, so many libraries developed their own website listings, 
sometimes driven by a database. After 2000 commercial products, known as electronic resource management systems (ERMS), were used to manage libraries' listings of e-journals, increasingly necessary with the huge numbers of items in subscription packages (Murdock, 2010) and attempts have been made to integrate this into ILS functionality (Jewell, 2009). According to Murdock (2010) the ERMS model envisages distributing routinized tasks through a number of library functions, and so potentially replaces the need for an Electronic Resources (ER) librarian as such, or at least, requires more emphasis on an ER co-ordinator role, across professionals throughout departments, all of whose roles would themselves have evolved. Work by Park and Lu (2009) and Park, Lu and Marion (2009) on cataloging/metadata professionals points to how these roles have also evolved in response to electronic resources and digital library initiatives. Yet there is no clear evidence in job advertisements between 2000 and 2008 that adoption of ERMS leads to the disappearance of the ER role, although the rising trend of job advertisements does seem to level out (Murdock, 2010). ERMS adoption has been patchy; it is probably too early to see how work will be reorganized once understanding of how to deliver e-books has been made routine and when resource discovery platforms have matured and been widely adopted. Then it will be clearer the extent to which all library operations have been reorganized around e-content and the consequences for roles.

Fisher's (2003) study of job advertisements in American Libraries traces the origin of the role to 1985 , but the first ER Librarian post as such was advertised in 1992. Since much of the initial online material was e-journals, there was a natural continuity of the ER role with that of the serials librarian. However, while the serials librarian has traditionally been seen as a technical services role, Fisher's (2003) early study tentatively suggested that the ER role evolved out of existing public service roles, rather than marking a revolutionary emergence of a new type of speciality. Bergman's (2005) finding that most have considerable library experience, rather than being new to the profession (and are women) reinforces the impression of the evolution of existing roles.

Engel and Robbins's (2008) study suggests that the specialist aspects of ER roles break down into three areas:

- Acquiring, evaluating, licensing e-resources

- Managing, maintaining, trouble-shooting

- Organizing through cataloguing or electronic resource management.

Murdock (2010) finds trouble-shooting increasingly mentioned. However, his figures suggest that the role of organization and the need for web skills, frequently referred to at the turn of the century, are now less often required, presumably because libraries have shifted from producing their own web guides to using commercial systems. Analysis of statistics could now be added to such a list of roles: Murdock's (2010) study shows a rise in the importance of this function in job advertisements and Henle (2008) sees a great opportunity to have a professional impact through imaginative use of statistics.

Job announcements for ER positions rarely suggest someone with managerial responsibilities. The picture confirms a view of an ER librarian as a "cross between a reference librarian, a collection development officer, acquisitions manager, a cataloger, and an information technology specialist" (Boss \& Schmidt, 2007; quoted in Murdock, 2010, p. 38). Indeed, there is a strong sense of ER librarianship not (yet) having developed as a marked specialism. Engel and Robbins's (2008) study 
suggests that the role is not strongly specialist, but rather one encompassing a wide range of roles. Murdock (2010) found job adverts continue to expect general competencies in reference and instruction, reinforcing Fisher's (2003) positioning of the role in public services. Sutton's (2011) major study of job advertisements in the USA between 2005 and 2009 showed that professional capabilities such as communication, working collaboratively and problem solving were the commonest attributes listed as actual requirements. Many advertisements also required knowledge of trends in the field. As Thompson (2009a, p. 23) observes, because of rapidly changing technologies many LIS jobs now require "flexibility, willingness to learn and ability to handle change" or the same competency, in whatever words it is expressed. However, in contrast, technical knowledge, such as of the ILS and link resolvers or of licensing and acquisitions, only appeared frequently as preferred attributes of candidates. Sutton (2011) interprets this to suggest that employers do not think people with the technical knowledge are available; but equally it could be an indication that forms of technical knowledge can be easily acquired, and it is more personal attributes and a library background that are needed to perform the ER role. The latter would imply that the role is not considered a particularly deep speciality.

Digital librarians

The digital library (DL) concept emerged in the early 1990s out of the National Information Infrastructure initiative in the USA (Bearman, 2007). With the rise of the web, the notion of DLs as discrete databanks was superseded by the vision of services operating in a networked environment. Digitization of special collections brought DL collections and services into the library. Commentators were quick to recognise new skills sets that would be required, such as project planning (Tanner, 2001).

Croneis and Henderson's (2002) study of job advertisements between 1990 and 2000 with the word "electronic" or "digital" in the job title in College \& Research Libraries News concluded that there were potentially two different roles, with ER roles showing much more continuity with traditional library work, while DL workers were "primarily responsible for administration and project management with emphases on securing funding and overseeing production". Choi and Rasmussen (2009, p.458) built on this finding to produce a definition for their 2006 study, focusing on roles "responsible for and involved in technology-based projects to deliver digital information resources in non-public service areas" - seeking with the last clause to exclude ER librarians or more public service focused roles. Their studies do seem to confirm the existence of a different set of roles here around the word "digital" and much of what we know about the specialty is derived from their two studies (Choi \& Rasumussen, 2006, 2009). Interestingly, their survey in 2005 found most digital librarians were new to the profession (with less than five years experience) and also to digital work (mostly less than three years). A third of respondents were in their thirties. A slight majority of respondents were female.

In the later study, the authors organized the competencies required in the advertisements within the ALA competency framework (Choi \& Rasmussen, 2009). Technical knowledge, such as current trends, knowledge of the web, general technical knowledge, were the most frequently mentioned as required competencies. Required experience was of the DL, web and ILS. Institution management competencies (such as communication and interpersonal skills, project management, management and supervision - but not budget management) were the second most common category. Resource building such as digitization was the next most common, but the percentage was low, and only once 
was preservation mentioned, for example. Knowledge organization (most often metadata standards knowledge) was mentioned. Intellectual property rights (IPR) was rarely mentioned. Thus the jobs require a high degree of specialist IT and information knowledge, combined with management, project management and interpersonal skills. Because of the project nature of a lot of DL work, managerial and soft skills, such as communication skills, were important. The authors comment on the criticality of knowledge of trend analysis (mirroring Sutton's (2011) findings for ER librarians). Tzoc and Millard (2011) confirm the importance of web design/standards and digital collection management skills. However, they found programming required much more often than Choi and Rasmussen did.

Choi and Rasumussen's work identifies a DL position, but there was no attempt to scope out DL development roles as conceived by computing or indeed other sectors. The authors did not collect data on where in the library structure the DL position was located. Surprisingly, the Core project that has developed an LIS DL curriculum (Pomerantz, Oh, Yang, Fox \& Wildemuth, 2006), never seems to have explored the job market in information systems or beyond. We could not locate any literature that did scope careers in the more IT-related aspects of DL work. Presumably, people with a computing background would consider themselves to be developers, who just happened to work in the DL field. DL work seems to be rarely taught as such on computer science courses (Pomerantz et al., 2006).

Repository managers

In the early years of the 21st century a number of key declarations and reports established a momentum behind a global Open Access (OA) movement to increase visibility of and access to publicly funded research outputs. One route to OA is depositing versions of research reports that have been published in commercial publications in open repositories (also known as open archives). A repository is "a set of services" offered "to the members of its community for the management and dissemination of digital materials created by the institution and its community members" (Lynch, 2003); it is effectively a form of digital library. From around 2005, a large number of such repositories has been created and this has led to the emergence of the role of repository manager. Despite the existence of many subject specialist repositories, most universities and research institutes in the USA and the UK now have their own institutional repository (IR). At some level much of the activity competes with commercial publishers' mechanisms to offer access to content.

Because of the repository's strong relation to existing library activities in the area of information access, the IR has tended to be located within the library sphere. Horwood, Sullivan, Young and Garner (2004) see a good fit between the LIS knowledge base and IR requirements in terms of collection management policy, designing permission and copyright agreements, training depositors and advocacy for deposit. Thus in surveys, of both the UK (Wickham, 2010) and Australia (Kennan \& Kingsley, 2009), more than three quarters of IR managers have a library background. Cassella and Moradon (2012) see a risk in this if it means that the repository is not run in such a way as to gain wider institutional buy in. In an optimistic vision, Walters (2007) sees the creation of IRs as an opportunity to expand the role of special collections departments, drawing in expertise from around the library, e.g. from catalogers, systems people and liaison librarians, in order to reposition the whole library at the hub of campus scholarly communications. In reality, the repository manager is likely to be in a more specialist role, maintaining one digital service among others. Indeed, repositories have not yet realized their promise. Some institutions or academic units within 
institutions (e.g. colleges, faculties or schools) mandate deposit; many funders do too (Xia et al., 2012). Notwithstanding this and despite the seemingly strong case in terms of increased visibility of research through $\mathrm{OA}$, persuading researchers to deposit their work remains one of the key challenges. As a result, only a small proportion of all published content is in IRs. This is reflected in the ambivalent positioning of the IR manager, of both being at the heart of a very promising area of development, but also suffering low resourcing. Thus Wickham (2010) found three quarters of repository managers were only working part-time in that role. Wickham also reports IR managers as saying they need both good planning skills and attention to detail, again implying the role has managerial but also routine administrative aspects. Cassella and Morando (2012) found that Italian repository managers were often working part-time and also that nearly half had been in post for less than three years.

Robinson (2009) has developed a convincing account of the staff and skills set for IR. This encompasses: management skills; knowledge of relevant software; more library related knowledge around metadata, storage and preservation, IPR and also knowledge of the scholarly publishing cycle. In a fast moving field there is reference to the need to keep up-to-date. The need to persuade departments and individual faculty members to participate in self or mediated deposit implies the importance of liaison, advocacy, training and support. The results of surveys of IR managers in the UK (Wickham, 2010) and Italy (Cassella \& Morando, 2012) confirm the importance of communication skills.

\section{Clinical librarians and informationists}

Although concepts from the specialist field of health sciences librarianship, the long history and high profile of medical libraries in pioneering the application of technology in information work mean that the roles of clinical librarian and informationist are important as indicators of possible trends in academic librarianship more generally. Reviews show that many clinical librarians and most informationists are based in universities (Rankin, Grefsheim \& Canto, 2008; Wagner \& Byrd, 2004). They also offer a significant model of how to organize the profession, with parallels in the newer data professional role. The Welch Medical Library at Johns Hopkins University has changed the title of all its liaison librarians to informationist, adopting a distributed model of embedded librarians and announcing plans to close the library building (Roderer, Lamont, Anton \& Obst, 2011).

Clinical librarianship $(\mathrm{CL})$ is an example of library "outreach" that integrates information professionals into patient care teams, primarily in teaching hospitals, through attendance at ward rounds and case conferences in clinical settings (Wagner \& Byrd, 2004; Winning \& Beverley, 2003). The model enables librarians to understand the specific context of information use and also to anticipate needs and deliver information before receiving requests. The role usually includes user education and is a specialized variant of the traditional liaison librarian found in academic libraries, described by Brown (2004, p. 46) as "a reference librarian who outreaches to clinical constituencies that have no time to come to the library". It also conforms to the emerging model of "embedded librarianship" promoted by Shumaker (2009, pp. 239-240), who cites examples in hospitals, universities, and other organizations, describing embedded librarians as "like bibliographic instruction librarians that have been totally immersed... where the librarian becomes a member of the customer community rather than a service provider standing apart". Brettle et al.'s (2010) review of 19 clinical librarian services (mainly in the UK) identifies four service models, including both outreach (where the librarian attends ward rounds or meetings in person) and static versions 
(where the librarian receives requests via phone, email, etc.), offering either a basic service (typically a literature search and/or training), or added value (such as a critically appraised summary or synthesis of results), noting that the latter comes closest to the concept of the "informationist".

Because clinical librarianship has not in practice been widely adopted, Davidoff and Florance (2000) argued that a new model was needed: they argued that the new informationists or "clinical knowledge workers" should be formally trained in both information science and clinical work, have a deep understanding of clinical practice and should report through the clinical hierarchy of their institutions, rather than being based in the library. The informationist is perceived as a "technology expert for [their] team" (Rankin et al., 2008, p. 198). The informatics dimension, which includes the ability to provide not only relevant electronic resources, but also information management software and "customized technology solutions" (Oliver \& Roderer, 2006, p. 44), is arguably a significant requirement that has not traditionally been associated with clinical librarians. To some degree the concept is anticipated in Abbott's (1998) speculation about the potential for a hybrid role between librarianship, scholarship and computer science. In practice, many informationist programs have evolved from CL programs. The US National Instiutes of Health (NIH) program has grown from two informationists to 15 within a decade. Described as "librarians trained in both biomedical subjects and information science... who work alongside researchers", their duties include "finding collaborators and experts, as well as creating Web pages, wikis, and databases", and a key feature here is "the idea of the informationist as a teammate who joins the physicians/researchers in their place of work" (Robison, Ryan \& Cooper, 2009, pp.5, 6, 12). However, Rankin et al. (2008) also identify examples deploying domain experts with information training, reporting an interesting difference of emphasis in the early stages of their programs between the technical focus of bioscience/bioinformatics informationists and the service focus of clinical informationists, which later disappears as both models mature into more holistic provision. The informationist concept has generated a significant quantity of literature in its relatively short history. Rankin et al.'s (2008) systematic review identified 107 substantive articles published between 2000 and 2006.

Digital curators/research data managers

The role of research data manager remains problematic compared with most of the others reviewed here. Associated particularly with advances in e-science (also known as "e-research" and "cyberscholarship"), the whole area is unsettled and beset by imprecise definition and inconsistent nomenclature. Many terms used in reports of official bodies can be interpreted either broadly or narrowly. Swan and Brown (2008), reporting on the roles, skills and career structures of "data scientists and curators", describe the terminological confusion found in the literature and explain how roles may be variously defined by the titles assigned or tasks performed; in addition, people in the field do not necessarily describe their jobs using the terms adopted and promoted by the LIS digital curation community (Harvey, 2010; Pryor, 2012). Swan and Brown (2008) identify four distinct, but still partially overlapping, roles:

- data authors/creators

- data scientists/specialists

- data managers

- data librarians/archivists. 
In their model, data managers are people with technical backgrounds in areas such as computational science, information technology or information science, while data scientists are either domain experts with high-level technical skills or computing/technology specialists with indepth domain knowledge (i.e. hybrid or blended professionals, similar to informationists). However, both these labels are also used more broadly as umbrella terms for specialists/professionals who work with and support researchers (as part of a research group, specialist institute, large data center or a central technology or research computing service) and whose jobs may cover a range of functions, from organizing, annotating and enhancing raw data to storing, securing and preserving datasets at the end of a project. Data scientists/managers with domain expertise often fulfil more specialist roles, such as input to the design of experiments and other "upstream" activities in the research process (Swan \& Brown, 2008).

The concept of data librarianship and the title data librarian (or data archivist) originated with social science data (particularly publicly available datasets and geospatial data), but then evolved to the bioinformatics field and now covers library-related work with both purchased and locally produced digital data in any subject domain (Gabridge, 2009; Gold, 2007; Soehner, Steeves \& Ward, 2010; Swan \& Brown, 2008). Some commentators question whether libraries and librarians have the capacity to engage with data-driven science at the level envisaged by those promoting their involvement, highlighting the domain knowledge and technical skills needed (Gabridge, 2009; Gold, 2007). Others have explained how data management activities can build on established practices and existing expertise in areas such as material selection, collection development, information organization, resource discovery, copyright advice, user education, academic liaison, repository management and digital preservation (Gabridge, 2009; Garritano \& Carlson, 2009; Soehner et al., 2010; Walters, 2009; Witt, 2008). Lyon (2012) argues that libraries could exploit the opportunities offered by data-intensive research to extend their role in supporting public engagement with science, by mediating public access to research datasets in institutional, disciplinary or national repositories and data centres and acting as hubs for citizen science.

Stanton et al. (2011, p. 91) depict e-science professionals as "a form of 'embedded librarianship' where information professionals serve right in the midst of the research and development activity along with scientists and technology specialists", noting that the roles filled by their students "hybridized their undergraduate studies [in science] with their professional involvement in librarianship" (p. 89). They also highlight the technological competencies needed for some jobs, ranging from database design and content management to data mining and programming. The level of domain expertise and technical know-how required for particular roles needs further investigation, but commentators generally agree that a breadth of skill sets is needed, including those associated with LIS, in addition to personal, interpersonal and managerial abilities (e.g. communication, partnership working, project management) and understanding of research methods and procedures in relation to all stages of the data lifecycle (Auckland, 2012; Garritano \& Carlson, 2009; Henty, 2008; Stanton, et al., 2011). The recent publication of books on e-science, digital curation and data management aimed specifically at library and information professionals, including both edited collections and a "how-to" manual (Marcum \& George, 2010; Harvey, 2010; Pryor, 2012), demonstrates growing acceptance that they have a major role to play in managing research data. 
Teaching librarians/information literacy educators

Variously described as tutor librarians, instruction librarians, learning advisers and teaching librarians, the educational role of library and information professionals goes back to the 19th century, when teaching people how to find and handle books and information was an accepted part of the personal assistance offered in academic, school and public libraries (Clyde, 2002). Academic librarians have engaged in formal instruction of students for more than a century, but the role has expanded and developed significantly in the last 30 years and also become specialized and professionalized (Albrecht \& Baron, 2002; Bewick \& Corrall, 2010; Walter, 2008; Westbrock \& Fabian, 2010). Different terms used for this work show how the emphasis has shifted not only from "library skills" to "information skills", but more fundamentally from programs described as "library orientation", "user education" and "bibliographic instruction" to broader conceptions of "information literacy education" and "research instruction" (Clyde, 2002; Lupton, 2002). Technological advances have created opportunities and threats for the free flow of information in society and raised awareness globally of the importance of information literacy for economic development, democratic participation, social cohesion and lifelong learning (Julien \& Genuis, 2011).

Professional associations have promoted the role of librarians in information literacy through definitions, standards, training and education (Albrecht \& Baron, 2002; Bewick \& Corrall, 2010; Clyde, 2002). The maturity of the field is shown by growing numbers of manuals and textbooks on information literacy teaching (Clyde, 2002), including specialist series (e.g. Neal-Schuman's Information Literacy Sourcebooks), as well as specialist conferences and discussion lists (Albrecht \& Baron, 2002). Practitioners increasingly assert that teaching is no longer a specialization within the profession, but central to all library work (Albrecht \& Baron, 2002; Bewick \& Corrall, 2010; Julien \& Genuis, 2011; Sproles et al., 2008; Walter, 2008). However, research points to practitioner ambivalence and even resentment towards their instructional role (Bewick \& Corrall, 2010; Julien \& Genius, 2011; Walter, 2008).

In academic libraries, information literacy education has traditionally been part of the job for subject, reference or liaison librarians, but has assumed more importance over the past decade (Albrecht \& Baron, 2002; Bewick \& Corrall, 2010; Houtman, 2010; Sproles et al., 2008; Westbrock \& Fabian, 2010), with growth in specialist positions with "information literacy" or "instruction" in their titles, including co-ordinating roles with a leadership or "quasi-managerial" dimension (Albrecht \& Baron, 2002; Clyde, 2002; Shank \& Dewald, 2012; Westbrock \& Fabian, 2010) and involvement of paraprofessional staff in instructional work (Julien \& Genius, 2011). The concept of the "teaching librarian" differs from the position of a "teacher-librarian", the term generally used for a teacher who takes on the role of librarian in a school (Lupton, 2002). Bell and Shank $(2004,2007)$ propose the concept of "blended librarian" who has skill sets from librarianship, pedagogy and technology. The role of teaching librarians is complex in both the range and context of the activities undertaken. Instruction ranges from ad hoc and pre-arranged individual assistance to creation of printed or online learning resources and formal teaching of small or large groups, sometimes in semester-long credit-bearing courses, but often delivered as "one shot" sessions that may not be effectively integrated into curricula (Bewick \& Corrall, 2010; Clyde, 2002; Julien \& Genuis, 2011; Polger \& Okamoto, 2010; Shank \& Dewald, 2012).

Relationships with teaching faculty and support from library administrators and colleagues are cited as key factors affecting performance in the role (Albrecht \& Baron, 2002; Houtman, 2010; Julien \& 
Genuis, 2011; Lupton, 2002; Walter, 2008). In addition, few professional librarians have received formal teacher education or training prior to taking on instructional responsibilities, with the vast majority of practitioners gaining and maintaining their pedagogical know-how on the job, through a mix of trial and error, in-service training and education, professional reading, mentoring and networks, although provision within Master's programs has increased gradually over the years (Albrecht \& Baron, 2002; Bewick \& Corrall, 2010; Clyde, 2002; Houtman, 2010; Julien \& Genuis, 2011; Sproles et al., 2008; Walter, 2008; Westbrock \& Fabian, 2010).

The inadequate preparation of LIS graduates for their instructional work is a recurring theme, with practitioners criticizing both educators and employers for not giving sufficient attention to the development of pedagogical knowledge and skills (Albrecht \& Baron, 2002; Bewick \& Corrall, 2010; Shank \& Dewald, 2012; Sproles et al., 2008; Westbrock \& Fabian, 2010). Professional identity is another key theme: in his exploration of "teacher identity" among librarians, Walter (2008, p. 55) notes the need to distinguish "between learning to teach and becoming a teacher". Existing research suggests a need for further investigation of the content and value of existing professional education offerings for teaching librarians, along with exploration of mentoring for new teachers and investigation of the significance of disciplinary knowledge in establishing credibility as a teacher.

Information and knowledge managers

The explosion of the amount of information used within all organizations, including academic institutions, points to the potential extension of information management (IM) as a generic version of the skills of librarianship to the management of all organizational information. Thus, according to Joint (2006), in running IRs it has become apparent that across institutions there is a wide range of materials that need better IM; in this context it seems logical to ask whether there is scope to expand the role for libraries discovered through IRs to manage all digital information of universities as organizations. Both Branin's (2003) Knowledge Bank concept and Conway's (2008) Content Landscape Model attempt to conceptualize how the IM needs of all types of content in the university can be understood systematically. The implication is that institutional content needs to be managed as a whole, and the tendency to treat each sort of content separately needs to be overcome.

Joint (2006) argues that the role in creating a digital asset management (DAM) system for the whole institution is a possible role for librarians, because of their awareness of metadata and standards issues. Branin (2003) identified a number of specific roles they could play, in terms of developing systems, gathering content and educating users. Yet it may be more likely that IT services would be seen as positioned to provide an infrastructure, e.g. to maintain and ultimately integrate a number of DAM systems. Initiatives will likely need to be collaborative across a range of specialties. Further, the importance of DAM being driven by value to the organizational mission (Conway, 2008) points to an issue common to many IM or KM related initiatives, that though they are a technical challenge (in IM or in IT terms), the premium is on business sense: on having a strong feel for the overall purposes of the organization. Librarians are not best placed to be seen as able to do this (Ferguson, 2004). Attempts, such as at the University of Hull, to generalize library functions to provide an IM service failed because potential customers of the service did not see IM as distinct from IT and the unit had an unclear identity that could not be understood by senior managers (Case, 2010). 
During the 1990s the applicability of KM to universities, as for other industry sectors, was also recognized (Cronin, 2001; Kidwell, Vander Linden \& Johnson, 2000; Loughridge, 1999). However, given the richness and fluidity of the concept of KM and its diffuse impact across the organization, consensus about the nature of roles created by KM has been hard to achieve. Different theoretical perspectives imply different emphases, while how KM is realized varies very much by sector (Abell, Chapman, Phillips, Stewart, \& Ward, 2006); perhaps even by organization, adapting to each unique culture (Burnstein, Sohal, Zyngier, \& Sohal, 2010). Several writers, across the corporate and public sectors, have identified significant roles for librarians and information professionals in the emergent practices of KM. The potential that librarians might play a central role was echoed in early writings on KM in the academic sector (e.g. Corrall, 1998; Loughbridge, 1999; Townley, 2001). In reality, there is little evidence that librarians play a dominant part in implementing KM in academia; a notable exception here is the University of Hong Kong Library's pivotal contribution to its institution's knowledge exchange strategy, but most published case studies focus on KM within libraries themselves (e.g. Ahumada \& Bustos, 2006; Gandhi, 2004; Stover, 2004). This may be because of KM's frequent focus on managing tacit and social knowledge, areas not associated with traditional librarianship.

The debates about the role of librarians in KM or in IM are put in a wider context by TFPL's studies of how e-information, in its broadest sense, is used and managed in the corporate and public sectors (Abell et al., 2006; Abell, Davies \& Hordle, 2011). Their conclusion was to propose a broad framework to encompass e-information roles. Some of the roles are closely related to familiar information work, such as organization of information, user support or addressing legal aspects. Such findings suggest that there are definite niches for information specialists, though it would be highly likely that they would involve operating in a multi-professional environment and require high levels of skill in persuasion and influencing. However, many more of the roles identified within the framework have their centre of gravity in IT, publishing and communications, advertising or human resources.

\section{Web managers and web teams}

The way that such IM work develops as a number of multi-professional practices, where information professional knowledge is far from being a dominant player, can also be illustrated from web management (Cox, 2007; Social Issues Research Centre, 2009). In the academic sector, the success of the web has meant all institutions have perceived a need to have a web presence; as the importance of the web has grown, the level of staffing and so specialization of web work has risen. Web work could be based in IT, because of the need to run the web server and to develop webbased applications. Yet in many other institutions more resources were put into the web roles in marketing and communications, because of the increasing centrality of the web both to how students were recruited and for internal communications. In the earliest stages a potential for web work was seen as either a role based in the library, or a more generic information role, in terms of requiring understanding of the organization of content and also information retrieval. The image of the library as about books and, at that time, the shallow engagement with digital technologies, meant that web management rarely stayed within the library domain. Librarians' knowledge about information organization did not simply translate to a web environment. The jurisdictional resolution came in an accommodation between computing and marketing, mediated by a content management system (CMS), separating technology support from content. Information aspects of the web such as search and information organization remain important challenges in web design. 
However, the expertise role in search is commodified in the search engine, while information organization is subordinated to more directly important knowledge sets of marketing and computing.

There was also in the late 1990s signs of the emergence of a library "webmaster" role (van der Walt \& van Brakel, 2000). This reflected the need to organize links to free content and later organize access to licensed material. Early university sites often had many links to useful sites; these moved to the library. But the move away from hand-crafted web pages to content management systems (CMS) and web-based systems, such as web OPACs and A-to-Z services, meant knowledge of the web was dispersed across many roles, and rarely remained an individual's main specialty.

\section{An Abbottonian interpretation}

The wider contexts, illustrated in Figure 1, are background trends such as the rise of managerialism, fuelled by the demands of the economy and general attacks on professions and their autonomy, the informalisation of work relations, and the dissolution of hierarchical communication structures through the use of communication technologies.

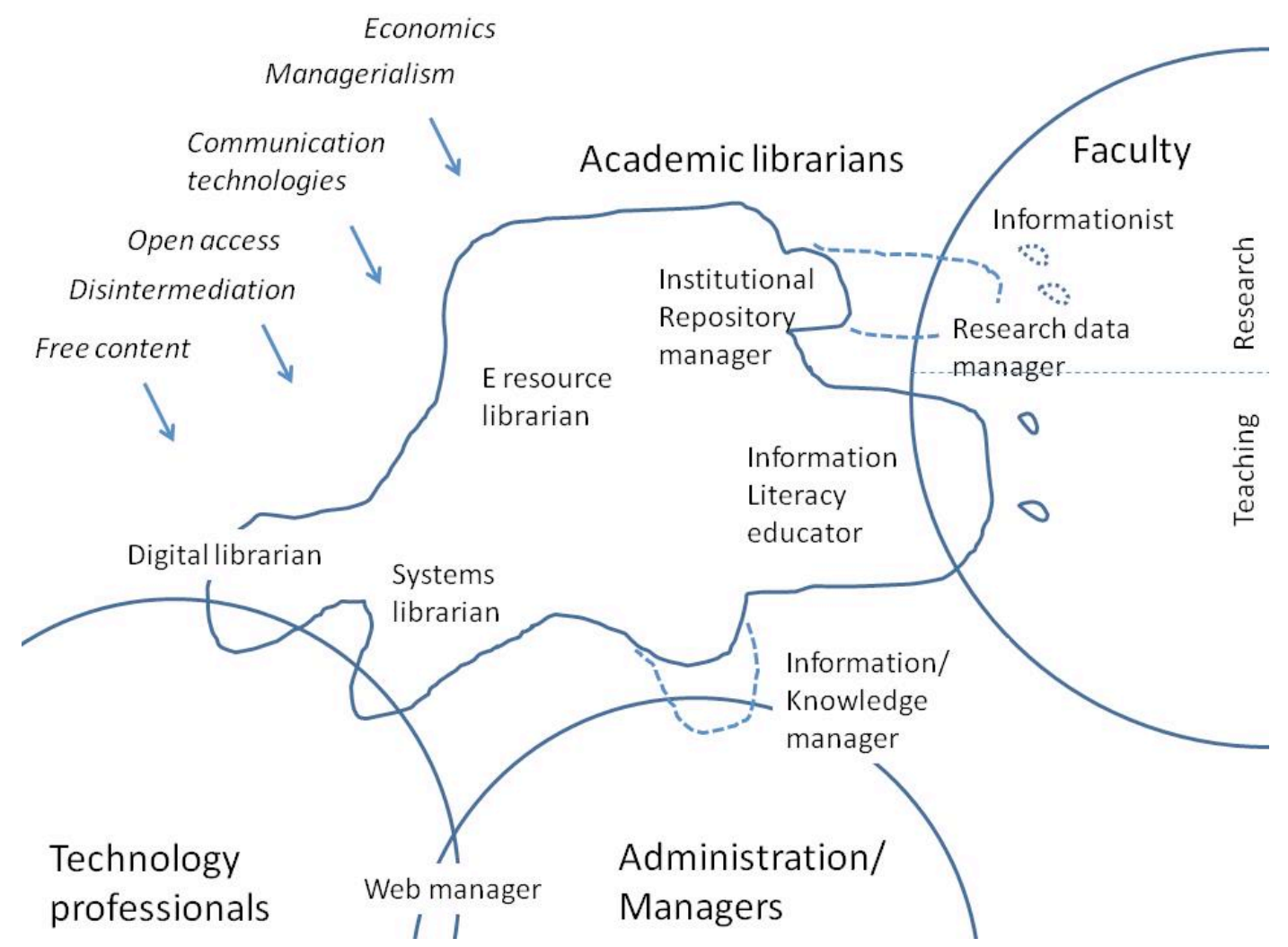

Figure $1 \mathrm{~A}$ jurisdictional map of academic librarianship.

In a context of greater fluidity, professional groups' struggles for jurisdiction are submerged. Across the specialties that we have reviewed, the pervasive requirement to communicate, be flexible and keep abreast of latest developments, reflects a continuously fluid picture driven by unpredictable changes in technology. Trends linked to IT and particularly the Internet, such as massive quantities of 
free content and easy disintermediated access, combined with the open access movement, all represent significant pressure on the access jurisdiction of the profession. Another important factor at work across the field may be that in a heavily gendered pattern of work segregation, female professional groups such as librarianship tend to be subordinated to male dominated ones such as computing (Bergman, 2005; Harris, 1999). A recurrent force is the wider economic cycle. In this context the neatly bounded "shape" and identity the profession had for most of the 20th century, is eroded, compressed, stretched and fragmented.

The reinvention of the access role in response to digitization and the Internet are not explored by Abbott (1998) or O'Connor (2008, 2010). Our data from the literature about the systems, electronic resources and digital librarian roles point to the way work has been shaped by new technologies. To date, the importance of highly specialized library systems has held in check the tendencies of enterprise computing for IT departments to draw in all technologies to the centre. Equally the jurisdiction over access has been maintained. Core roles across the library have been reinvented to adjust to the demands of managing electronic content rather than print. The evidence from digital library roles also points to the control over digitization and preservation of items born digital, again potentially in competition with computing professionals - an issue that is currently being debated in the context of research data management. In these cases, knowledge of information and communication technologies (ICTs) is assumed to be subsidiary to understanding of collection development and management. Success in preserving the jurisdiction perhaps partly reflects the limited development of computing/technology as a profession (Adams \& Dematier, 2008). Webscale discovery systems offer the probability of resisting the competition for the access jurisdiction from Google (Way, 2010). Yet it remains the case that with proliferation of content on the web, free and open access may have significantly undermined the clarity of the access jurisdiction that was historically the cornerstone of academic librarianship. Given the close association of the public image of librarianship with the printed book, the potential impact of the decline in relative importance of print materials probably constitutes the single most significant factor shaping the professional future. The sense of crisis in the professional literature arises from this insecurity. Yet the growth in the quantity of knowledge in society that brought the need for modern librarianship (Winter, 1988) continues, perhaps accelerates. The further fragmentation of the social organisation of academic knowledge into proliferating specialisms combined with a drive to make novel interdisciplinary connections makes the organisation of knowledge more complex and this in turn ensures a need for librarianship as "applied metascience ... the study of how the universe of published records of knowledge is organized" ( Winter 1988, p.8). Further, the revival of a role in preservation, now through digitisation of special collections, is also a trend that stabilises a familiar library role.

Repository management, informationism and data curation are more expansionist projects, seemingly seeking to expand the profession's access jurisdiction into new areas, exploiting opportunities created by technology and wider policy change. Institutional repositories expand the access jurisdiction to local content and also represent, in Abbott's terminology, competition with publishers as expert organizations. Indeed, academic libraries are increasingly formally involved in managing university presses (Hahn, 2010; Crow et al, 2012). The informationist concept imagines a hybrid LIS professional embedded in a practice context. Data curation inserts information roles earlier into the chain of scholarly research and carries it through to the management of research data and its later preservation for reuse. This pushes into the area of the work of researchers, 
though in a supporting role. Both these thrusts can be understood as expansions that have a high appeal because they reflect extensions of the existing jurisdiction around access and because the association with scholarship also has high status within an academic institution. For Abbott they should be seen as competitive with other occupations, yet as supportive of the enterprise of research, probably "subordinate" to it. As with the move into information and knowledge management in the corporate sector, it is ambiguous whether this is inherently an expansionist move or reflects a response to the pressure on the core access jurisdiction. The moderate success of IRs to date might make us pause to reflect on how successful either initiative is likely to be. The profession can expand its cognitive jurisdiction if its abstract knowledge base provides solutions for the new area of work, but also only if it has numbers.

Information literacy represents a further attempt to extend jurisdiction, in this case in terms of the teaching role. While explaining what is in the collection has always been an aspect of librarianship, a fully fledged educational role is more novel, particularly in the academic context. Here the abstract knowledge base of the profession seems to be less likely to be efficacious and a lot of work needs to be done to integrate pedagogic theory. Partly the success of any such claims would reflect the coherence of response of faculty, themselves organized in a very fragmented and over-stretched set of communities. They might give ground since the teaching role is often seen by faculty as of lower status than research. Usually information literacy is presented as essentially subordinated to academic subject knowledge, although Johnston and Webber (2006) have made a case for information literacy to be regarded as a discipline in its own right.

Less successful have been the few attempts to expand control over generic information processes within universities. Web management is a case in point. Whereas some writers from the library sector have anticipated the easy or dominant translation of library/information skills to the emergent area of work arising from the move to a "knowledge economy" where information/knowledge is recognized as a core strategic asset, this has proved, in reality, not to have happened in a straightforward way. New roles are probably more likely to be seen as IT based, though often customer focused, or to have a large element of communications/marketing, as much as information work. As the roles are often also seen as being essentially linked to an understanding of the core business of the organization, they could also be seen as roles for managers/administrators. Further, given the slow moving nature of the public image of the profession, tied through dominant professional subgroups to the physical library and access function, it was likely to be hard for librarians simply to transfer their skills to the new problem areas.

Further, the e-information environment delineated by Abell et al. (2006) is far from being a stable occupational field. On the one hand, it is true that newly created roles offer many new opportunities and the potential for organizational impact. There are pragmatic benefits in breaking out of silos to work closely with users so that there is direct knowledge of user need. On the other hand, the fluidity of the context implies a high level of risk and uncertainty. The information identity is more blurred, less easy to explain, especially in any cases where professionals are embedded in multidisciplinary contexts. The roles are likely to be demanding in terms of gaining new competencies and then keeping up-to-date. High levels of hybridity or blending (Corrall \& Lester, 1996; Corrall, 2010) imply a high amount of skill and a lot of effort in learning new skills, without it being clear which skill set is the most valued in the long run. Such roles demand high level influencing and collaborative 
skills to work with others effectively. Much work is outsourced. A likely trajectory is that rather than achieving professionalization, the field will be marked by the rapid appearance and disappearance of niche expert roles (Scarborough, 1996). Management will be dominant and "professionalism" could be a disciplining discourse used by managers to control the workforce (Evetts, 2003). Understood in this way, it is not surprising that, if the choice is available, many information professionals might be cautious about moving away from clearly defined, credentialized professional domains. In the academic sector the continuing strength of the access role allows more tenuous claims to jurisdiction such as in IM or KM to be left uncultivated.

\section{Conclusions}

The perspective of Abbott's theory prompts us to consider a complex dynamic historical process of change, shaped by many types of contingent factors. His preoccupation, however, is with jurisidictional conflict between adjacent professional groups. Seen through this lens we can say that in the academic library sector, what Abbott identifies as the core work of the profession, access, has been defended. Yet trends such as massive quantities of free content, disintermediation and open access require it to be reinvented. The clarity with which a new concept of collection or library emerges is likely to shape how stable the defended access role is. At the same time there have been tentative forays to expand the jurisdiction of the profession into new areas. The main thrust seems to be towards information literacy. Other more recent moves have been into managing local research outputs and research data. Although often presented as offensive strikes, these moves can also be viewed as defensive strategies, adopted because the traditional version of the access role is under challenge, rather than simply expanding into new areas because of the increasingly pervasive need for information. The long-term success of such forays will be influenced by a number of factors, including the efficacy of the profession's knowledge base in that area or its ability to absorb other knowledge bases, the plausibility with which new roles can be equated to the existing public image of the profession, and the organization and posture of other professions that are jostling for position.

Some of these trends effectively defend the core jurisdictions of the profession. Others are much more likely to produce hybrid roles or favor embedding LIS professionals within wider processes. As they are created, hybrid or embedded roles may seem exciting and interesting. They are potentially very significant to rethinking how work is understood. Yet within Abbott's logic they seem problematic. They lack clear identity, both for the self and for others. Their status is somewhat uncertain; resourcing unsatisfactory. Such roles are likely to be demanding in terms of acquiring and maintaining an up-to-date knowledge base. Within the context of the wider professional project it is a weak positioning, even if an attractive role for individuals. Abbott's is a theory of professions not individual careers. Nevertheless, the increasing power of managerialism and the eclipse of professional autonomy may place many professions in this position in somewhat fragmented, embedded patterns, such as we already see in the corporate sector. Intra-professional competition, so central to Abbott's theory, is in this context dampened. Professional autonomy gives way to a stress on collaboration, persuasion and boundary crossing.

The data on which this paper is based have a number of limits. It has dealt exclusively with writing in the English language, and primarily with literature from the USA and the UK. Patterns in other countries could be different, indeed are likely to be so, because the evolution of LIS has been 
different in other countries, and because of the significance placed by Abbott on the occupational structure as a whole. By focusing on new specialties in academia we have developed one understanding of LIS as an occupation. The same factors that have created new specialties are actively reshaping existing roles. The bigger picture for Abbott would be the trajectory and organization of adjacent professions.

Furthermore, a literature-based study is inevitably shaped by the practices of publication. This means that academic specialties were possible to investigate, because of the amount of literature. The more complex picture outside one of the heartlands of LIS practice (Abbott, 1988) would inevitably be much less easy to understand, but also there is far less literature to help us construct it.

As in so much of the library-related literature the quality of the research on which it is based is mixed. There is a need to:

- Improve the quality of studies, through more rigorous methods (more transparent descriptions of method, the application of statistical tests to survey and job advert findings and the sharing of data, where possible), through data triangulation (with many more indepth qualitative studies), and by drawing on theoretical resources;

- Undertake the research in a way that increases the scope for longitudinal, cross-sectoral and international comparisons, e.g. by developing and using competency frameworks;

- Expand the range of studies across all sectors of information work.

Needless to say this is easier to write than to do. The motive of authors is often pragmatic, such as to support the development of a curriculum for a newly emerged field. The history of a profession within a country has significant bearing on the outcome of professional struggles around new areas of work. This makes meaningful international comparison difficult. Particularly in very fluid and complex areas, with marked industry sector differences, such as the IM and KM fields, establishing a competency framework that works over time is challenging. Nevertheless, the motives to produce research in this area are strong, since it relates to understanding the whole trajectory of the profession. The current paper has helped to make better research in this area possible by presenting a more systematic evaluation of the research methods in use; drawing attention to the work described as a field of study; and building a theoretically driven overview based on Abbott's work.

\section{References}

Abbott, A. (1988). The system of professions. Chicago: University of Chicago Press.

Abbott, A. (1998). Professionalism and the future of librarianship. Library Trends, 46, 430-443.

Abell, A., Chapman, D., Phillips, P., Stewart, H., \& Ward, S. (2006). Roles in the e-landscape: Who is managing the information? Business Information Review, 23, 241-251.

Abell, A., Davies, J., \& Hordle, J. (2011). Connecting information with innovation: TFPL's 2011 survey of skills and roles, TFPL. Retrieved from http://www.tfpl.com/resources/tfpl-reports.cfm.

Abels, E., Jones, R., Latham, J., Magnoni, D., \& Marshall, J.G. (2003). Competencies for information professionals of the 21st century (rev. ed.). Alexandria, VA: Special Libraries Association. Retrieved from http://www.sla.org/PDFs/Competencies2003_revised.pdf.

Adams, T.L. and Demaiter, E.I. (2008). Skill, education and credentials in the new economy: the case of information technology workers. Work Employment Society, 22, 352-362. 
Ahumada, L., \& Bustos, A. (2006). Management of knowledge, information and organizational learning in university libraries. Libri, 56, 180-190.

ALA (2009). ALA's core competences of librarianship (final version). Chicago, IL: American Library Association. Retrieved from http://www.ala.org/ala/educationcareers/careers/corecomp/corecompetences/index.cfm.

Albrecht, R., \& Baron, S. (2002). The politics of pedagogy: Expectations and reality for information literacy in librarianship. Journal of Library Administration, 36(1/2), 71-96.

Auckland, M. (2012). Re-skilling for research: An investigation into the role and skills of subject and liaison librarians required to effectively support the evolving information needs of researchers. London: RLUK, Research Libraries UK. Retrieved from http://www.rluk.ac.uk/content/re-skillingresearch.

Backhaus, K.B. (2004). An exploration of corporate recruitment descriptions on monster.com. Journal of Business Communication, 41, 115-136.

Barley, S. (1996). Technicians in the workplace: Ethnographic evidence for bringing work into organization studies. Administrative Science Quarterly, 41, 404-441.

Bearman, D. (2007). Digital libraries, Annual Review of Information Science and Technology, 41, 223272.

Bergman, B.J. (2005). Looking at electronic resources librarians: Is there gender equity within this emerging specialty? New Library World, 106, 116-127.

Bell, S.J., \& Shank, J.D. (2004). The blended librarian: A blueprint for redefining the teaching and learning role of academic librarians. College \& Research Libraries News, 65, 372-375. Retrieved from http://crln.acrl.org/content/65/7/372.full.pdf.

Bell, S.J., \& Shank, J.D. (2007). Academic librarianship by design: A blended librarian's guide to the tools and techniques. Chicago, IL: American Library Association.

Bewick, L., \& Corrall, S. (2010). Developing librarians as teachers: A study of their pedagogical knowledge. Journal of Librarianship and Information Science, 42, 97-110.

Branin, J. J. (2003). Knowledge management in academic libraries: Building the knowledge bank at the Ohio State University. Journal of Library Administration, 39(4), 41-56.

Breeding, M. (2009). Libraries thrive through enterprise computing. Computers in Libraries, 29(6), 34-36.

Brettle, A., Maden-Jenkins, M., Anderson, L., McNally, R., Pratchett, T., Tancock, J., Webb, A. (2010). Evaluating clinical librarian services: A systematic review. Health Information and Libraries Journal, 28, 3-22.

Brown, H.-A. (2004). Clinical medical librarian to clinical informationist. Reference Services Review, $32,45-49$.

Burns, E. (2007). Positioning a post-professional approach to studying professions, New Zealand Sociology, 22, 69-98.

Burstein, F., Sohal, S., Zyngier, S., \& Sohal, A. S. (2009). Understanding of knowledge management roles and responsibilities: A study in the Australian context. Knowledge Management Research and Practice, 8, 76-88.

Case, V. (2010). The extended remit of university librarians reinvented as information managers: An investigation into the information management team at the University of Hull (Unpublished master's dissertation)...University of Sheffield, Sheffield, UK. 
Cassella, M., \& Morando, M. (2012). Fostering new roles for librarians: Skills sets for repository managers - results of a survey in Italy. LIBER Quarterly, 21, 407-428. Retrieved from http://liber.library.uu.nl/publish/articles/000553/article.pdf.

Choi, Y., \& Rasmussen, E. (2009). What is needed to educate future digital librarians? D-Lib Magazine, 12(9). Retrieved from http://www.dlib.org/dlib/september06/choi/09choi.html.

Choi, Y., \& Rasmussen, E. (2009). What qualifications and skills are important for digital librarian positions in academic libraries? A job advertisement analysis, Journal of Academic Librarianship, 35, 457-467.

Clyde, L. (2002). An instructional role for librarians: An overview and content analysis of job advertisements. Academic \& Research Libraries, 33, 150-167.

Conway, P. (2008). Modeling the digital content landscape in universities, Library Hi Tech, 26, 342354.

Corrall, S. (1998). Knowledge management: Are we in the knowledge management business? Ariadne, 18. Retrieved from http://www.ariadne.ac.uk/issue18/knowledge-mgt/

Corrall, S. (2010). Educating the academic librarian as a blended professional: A review and case study. Library Management, 31, 567-593.

Corrall, S., \& Lester, R. (1996). Professors and professionals: On changing boundaries. In R. Cuthbert (Ed.) Working in higher education (pp. 84-100). Buckingham: Society for Research into Higher Education \& Open University Press.

Cox, A. M. (2007). The power and vulnerability of the 'new professional': Web management in UK universities. Program, 41, 148-170.

Croneis, K.S., \& Henderson, P. (2002). Electronic and digital librarian positions: A content analysis of announcements from 1990-2000. Journal of Academic Librarianship, 28, 232-237.

Cronin, B. (2001). Knowledge management, organizational culture and Anglo-American higher education. Journal of Information Science, 27, 129-137.

Crow, R., Ivins, O., Mower, A., Nesdill, D., Newton, M., Speer, J., \& Watkinson, C. (2012). Library publishing services: Strategies for success. Washington, DC: SPARC, The Scholarly Publishing \& Academic Resources Coalition. Retrieved from http://wp.sparc.arl.org/lps/.

Danner, R.A. (1998). Redefining a profession. Law Library Journal, 90, 315-356.

Davidoff, F., \& Florance, V. (2000). The informationist: A new health profession? Annals of Internal Medicine, 132, 996-998.

Engel, D., \& Robbins, S. (2008). Evolving roles for electronic resources librarians. In H. Yu \& S. Breivold (Eds.). Electronic resource management in libraries: Research and practice (pp. 105-120). Hershey, PA: Information Science Reference.

Evetts, J. (2003). The sociological analysis of professionalism. International Sociology, 18, 395-415.

Evetts, J., Gadea, C., Sánchez, M., \& Sáez, J. (2009). Sociological theories of professions: Conflict, competition and cooperation. In A. Denis, \& D. Kalekin-Fishman (Eds.), The ISA handbook in contemporary sociology: Conflict, competition, cooperation. (pp. 140-155). London: SAGE Publications Ltd.

Ferguson, S. (2004). The knowledge management myth: Will the real knowledge managers please step forward? Proceedings of the ALIA 2004 Biennial Conference: Challenging Ideas, Gold Coast Convention and Exhibition Centre, Queensland, 21-24 September. Retrieved from http://conferences.alia.org.au/alia2004/conference.papers.html.

Fisher, W. (2003). The electronic resources librarian position: A public services phenomenon? Library Collections, Acquisitions, \& Technical Services, 27, 3-17. 
Freidson, E. (1994). Professionalism reborn: Theory, prophecy and policy. Chicago: University of Chicago Press.

Gabridge, T. (2009). The last mile: Liaison roles in curating science and engineering research data. Research Library Issues, 265, 15-21. Retrieved from http://www.arl.org/bm doc/rli-265gabridge.pdf.

Gandhi, S. (2004). Knowledge management and reference services. Journal of Academic Librarianship, 30, 368-381.

Garritano, J.R., \& Carlson, J.R. (2009). A subject librarian's guide to collaborating on e-science projects. Issues in Science and Technology Librarianship, 57. Retrieved from http://www.istl.org/09-spring/refereed2.html.

Gold, A. (2007). Cyberinfrastructure, data, and libraries, part 2. Libraries and the data challenge: Roles and actions for libraries. D-Lib Magazine, 13(9/10). Retrieved from http://www.dlib.org/dlib/september07/gold/09gold-pt2.html

Goode, W.J. (1961). The librarian: From occupation to profession? Library Quarterly, 31, 306-320.

Gorman, E. H. \& Sandefur, L.R. (2011). 'Golden Age,' Quiescence, and Revival: How the Sociology of Professions Became the Study of Knowledge-Based Work, Work and Occupations, 38, 275-302.

Guinea, J. (2003). Building bridges: The role of the systems librarian in a university library. Library $\mathrm{Hi}$ Tech, 21, 325-332.

Hahn, K.K. (2008). Research library publishing services: New options for university publishing. Washington, DC: Association of Research Libraries. Retrieved from http://www.arl.org/bm doc/research-library-publishing-services.pdf.

Harris, R.M. (1999). Gender and technology relations in librarianship. Journal of Education for Library and Information Science, 40, 232-246.

Harvey, R. (2010). Digital curation: A how-to-do-It manual. London: Facet.

Henle, A. (2008). Electronic resources (ER) librarians, usage data, and a changing world. Collection Management, 32, 277-288.

Henty, M. (2008). Developing the capability and skills to support eResearch. Ariadne, 55. Retrieved April 28, 2012, from http://www.ariadne.ac.uk/issue55/henty/.

Horwood, L., Sullivan, S., Young, E., \& Garner, J. (2004). OAI compliant institutional repositories and the role of library staff. Library Management, 25, 170-176.

Houtman, E. (2010). "Trying to figure it out": Academic librarians talk about learning to teach. Library and Information Research, 34(107), 18-40. Retrieved from http://www.lirgjournal.org.uk/lir/ojs/index.php/lir/article/view/246/303.

Iglesias, E. (Ed.) (2010). An overview of the changing role of systems librarian: Systemic shifts. Oxford: Chandos.

Jewell, T. D. (2009). Electronic resource management in libraries. In M.J. Bates \& M.A. Maack (Eds.). Encyclopedia of Library and Information Sciences ( $3^{\text {rd }}$ ed., pp. 1689-1698). New York: CRC Press. Johnston, B., \& Webber, S. (2006). As we may think: Information literacy as a discipline for the information age. Research Strategies, 20(3), 108-121.

Joint, N. (2009). Practical digital asset management and the university library. Library Review, 58, 8996.

Jones-Evans, A. (2005). Bangor university library service: An update. Journal of Librarianship and Information Science, 37, 115-117.

Jordan, M. (2003). The self-education of systems librarians. Library Hi Tech, 21, 273-279. 
Julien, H., \& Genuis, S.K. (2011). Librarians' experiences of the teaching role: A national survey of librarians. Library \& Information Science Research, 33, 103-111.

Kennan, M.A., \& Kingsley, D.A. (2009). The state of the nation: A snapshot of Australian institutional repositories, First Monday, 14(2). Retrieved from http://firstmonday.org/htbin/cgiwrap/bin/ojs/index.php/fm/article/view/2282/2092.

Kidwell, J.J., Vander Linde, K. M., \& Johnson, S. L. (2000). Applying corporate knowledge management practices in Higher Education. Educause Quarterly, 23(4), 28-33.

Lavagnino, M.B. (1997). Networking and the role of the academic systems librarian. College \& Research Libraries, 58, 217-231. Retrieved from http://crl.acrl.org/content/58/3/217.full.pdf.

Lim, S. (2007). Library informational technology workers: Their sense of belonging, role, job autonomy, and job satisfaction. Journal of Academic Librarianship, 33, 492-500.

Lim, S. (2008). Job satisfaction of information technology workers in academic libraries. Library \& Information Science Research. 30, 115-121.

Loughridge, B. (1999). Knowledge management, librarians and information managers: Fad or future? New Library World, 100, 245-253.

Lupton, M. (2002). The getting of wisdom: Reflections of a teaching librarian. Australian Academic \& Research Libraries, 33, 75-85. Retrieved from http://alia.org.au/publishing/aarl/33.2/full.text/lupton.html.

Lynch, C. (2003). Institutional repositories: Essential infrastructure for scholarship in the digital age. ARL: A Bimonthly Report, 226, 1-7. Retrieved from http://www.arl.org/bm doc/br226ir.pdf.

Lyon, L. (2012). The informatics transform: Re-engineering libraries for the data decade. International Journal of Digital Curation, 7(1), 126-138. Retrieved from http://ijdc.net/index.php/ijdc/article/view/210/279

Marcum, D.B., \& George, G. (Eds.). (2010). The data deluge: Can libraries cope with e-science? Santa Barbara, CA: Libraries Unlimited.

Murdock, D. (2010). Relevance of electronic resource management systems to hiring practices for electronic resources personnel. Library Collections, Acquisitions \& Technical Services, 34, 25-42.

Nalebuff, B.J., \& Brandenburger, A.M. (1997). Co-opetition: Competitive and cooperative business strategies for the digital economy. Strategy \& Leadership, 25(6), $28-35$.

Nicholas, D., Rowlands, I., Jubb, M. \& Jamali, H.R. (2010). The impact of the economic downturn on libraries: With special reference to university libraries. Journal of Academic Librarianship, 36, 376-382.

O'Connor, L. (2008). Information literacy as professional legitimation: The quest for professional jurisdiction. Library Review, 58, 272-289.

O'Connor, L. (2010). Information literacy as professional legitimation: The quest for a new jurisdiction. Library Review, 58, 493-508.

Oliver, K.B., \& Roderer, N.K. (2006). Working towards the informationist. Health Informatics Journal, $12,41-48$

Palmer, D.T. (2010). The HKU scholars hub: Unlocking collective intelligence. In T. Hedlund \& Y. Tonta (Eds.). Publishing in the networked world: Transforming the nature of communication, 14th International Conference on Electronic Publishing 16 - 18 June 2010, Helsinki, Finland (pp. 205216). Helsinki: Hanken School of Economics. Retrieved from https://helda.helsinki.fi/handle/10227/599.

Park, J., \& Lu, C. (2009). Metadata professionals: Roles and competencies as reflected in job announcements 2003-2006. Cataloging and Classification Quarterly, 47(2), 145-160. 
Park, J., Lu, C., \& Marion, L. (2009). Cataloging professionals in the digital environment: A content analysis of job descriptions. Journal of the American Society for Information Science and Technology, 60, 844-857.

Pfohl, D., \& Hayes, S. (2001). Today's systems librarians have a lot to juggle. Computers in Libraries, 21(10), 30-33.

Polger, M.A. (2010). "Can't anyone be a teacher anyway?" Student perceptions of academic librarians as teachers. Library Philosophy and Practice, March, 1-16 . Retrieved from http://www.webpages.uidaho.edu/ mbolin/polger-okamoto.htm.

Pomerantz, J., Oh, S., Yang, S., Fox, E.A., \& Wildemuth, B.M. (2006). The core: Digital library education in library and information science programs. D-lib Magazine, 12(11). Retrieved from http://www.dlib.org/dlib/november06/pomerantz/11pomerantz.html

Rankin, J.A., Grefsheim, S.F., \& Canto, C.C. (2008). The emerging informationist specialty: A systematic review of the literature. Journal of the Medical Library Association, 96, 194-206. Retrieved from http://www.ncbi.nlm.nih.gov/pmc/articles/PMC2479064/pdf/mlab-96-03-194.pdf.

Ray, M.S. (2001). Shifting sands - the jurisdiction of librarians in scholarly communication. Paper presented at ACRL Tenth National Conference, Denver, Colorado, 15-18 March. Retrieved from http://www.ala.org/ala/acrl/acrlevents/mray.pdf.

Rhyno, A. (2003). From library systems to mainstream software: How web technologies are changing the role of systems librarian. Library Hi Tech, 21, 289-296.

Robinson, M. (2009). Institutional repositories: Staff and skills set, SHERPA project. Retrieved from http://www.sherpa.ac.uk/documents/Staff_and_Skills_Set_2009.pdf.

Robison, R.R., Ryan, M.E., \& Cooper, I.D. (2009). Inquiring informationists: A qualitative exploration of our role. Evidence Based Library and Information Practice, 4(1), 4-16. Retrieved from http://ejournals.library.ualberta.ca/index.php/EBLIP/article/view/4192.

Roderer, N.K., Lamont, A., Anton, B., \& Obst, O. (2011). The closing of the Welch Library building: Interview with the Director, Nancy Roderer. Journal of the European Association for Health Information and Libraries, 7(4), 7-10. Retrieved from http://www.eahil.net/journal/journal_2011_vol7_n4_welchlibrary.pdf.

Scarbrough, H. (1996). The management of expertise. London: Macmillan.

SCONUL (2009). HEFCE shared services study: Business case. Bristol: Higher Education Funding Council for England. Retrieved from http://www.hefce.ac.uk/media/hefce1/finance/shared/feasibility/reports/FS61.pdf.

Seadle, M. (2003). The status of systems librarians. Library Hi Tech, 21, 367-269.

Shank, J.D., \& Dewald, N.H. (2012). Academic library administrators' perceptions of four instructional skills. College \& Research Libraries, 73, 78-93. Retrieved from http://crl.acrl.org/content/73/1/78.full.pdf.

Shumaker, D. (2009). Who let the librarians out? Embedded librarianship and the library manager. Reference \& User Services Quarterly, 48, 239-242, 257. Retrieved from http://rusa.metapress.com/content/lk361771rwp78790/fulltext.pdf.

Snyman, R.M.M. (2001). Do employers really know what they want? An analysis of job advertisements for information and knowledge managers. Aslib Proceedings, 53, 273-281.

Social Issues Research Centre (2009). Investigation into the management of web content in Higher Education Institutions. Retrieved from http://www.eduserv.org.uk/assets/eduserv\%20areas/research/studies/eduservwcmreport.pdf. 
Soehner, C. Steeves, C., \& Ward, J. (2010). e-Science and data support services: A study of ARL member institutions. Washington, DC: Association of Research Libraries. Retrieved from http://www.arl.org/bm doc/escience_report2010.pdf.

Sproles, C., Johnson, A.M., \& Farison, L. (2008). What the teachers are teaching: How MLIS programs are preparing academic librarians for instructional roles. Journal of Education for Library and Information Science, 49, 195-209.

Stanton, J.M., Kim, Y., Oakleaf, M., Lankes, R.D., Gandel, P., Cogburn, D., \& Liddy, E.D. (2011). Education for eScience professionals: Job analysis, curriculum guidance, and program considerations. Journal of Education for Library and Information Science, 52, 79-94.

Stover, M. (2004). Making tacit knowledge explicit: The Ready Reference Database as codified knowledge. Reference Services Review, 32, 164-173.

Sutton, S.W. (2011). Identifying core competencies for electronic resources librarians in the twentyfirst century library (Unpublished PhD dissertation). Texas Woman's University, Denton, Texas.

Swan, A., \& Brown, S. (2008). The skills, role and career structure of data scientists and curators: An assessment of current practice and future needs. Truro: Key Perspectives. Retrieved from http://www.jisc.ac.uk/publications/documents/dataskillscareersfinalreport.aspx.

Tanner, S. (2001). Librarians in the digital age: planning digitization. Program 35 (4), 327-337.

Thompson, S.M. (Ed.) (2009). Core technology competencies for librarians and library staff. New York: LITA/Neal Schuman.

Townley, C.T. (2001). Knowledge management and academic libraries. College \& Research Libraries, 62, 44-55. Retrieved from http://crl.acrl.org/content/62/1/44.full.pdf.

Tzoc, E., \& Millard, J. (2011).Technical skills for new digital librarians. Library Hi Tech News, 28(3), $11-$ 15.

van der Walt, P.W., \& van Brakel, P.A. (2000). Task analysis of the webmaster: Results of an empirical study. Aslib Proceedings, 52, 20-38.

Van House, N.A., \& Sutton. S.A. (1996). The panda syndrome: An ecology of LIS education. Journal of Education for Library and Information Science, 37, 131-147.

Wagner, K.C., \& Byrd, G.D. (2004). Evaluating the effectiveness of clinical medical librarian programs: A systematic review of the literature. Journal of the Medical Library Association, 92, 14-33.

Walter, S. (2008). Librarians as teachers: A qualitative inquiry into professional identity. College \& Research Libraries, 69, 51-71. Retrieved from http://crl.acrl.org/content/69/1/51.full.pdf.

Walters, T.O. (2007). Reinventing the library: How repositories are causing librarians to rethink their professional roles. Portal: Libraries and the Academy, 7, 213-215.

Walters, T.O. (2009). Data curation program development in U.S. universities: The Georgia Institute of Technology example. International Journal of Digital Curation, 3(4), 83-92. Retrieved from http://www.ijdc.net/index.php/ijdc/article/viewFile/136/153.

Way, D. (2010). The impact of web-scale discovery on the use of a library collection. Serials Review, $36,214-220$.

Westbrock, T., \& Fabian, S. (2010). Proficiencies for instruction librarians: Is there still a disconnect between professional education and professional responsibilities? College \& Research Libraries, 71, 569-590. Retrieved from http://crl.acrl.org/content/71/6/569.full.pdf.

Wickham, J. (2010). Repository management: An emerging profession in the information sector. London: Online Information 2010, 30 November-2 December, Olympia, London, UK. Retrieved from http://eprints.nottingham.ac.uk/1511/3/Online_paper_Jackie_Wickham.pdf. 
Winning, M.A., \& Beverley, C.A. (2003). Clinical librarianship: A systematic review of the literature. Health Information and Libraries Journal, 20 (suppl. 1), 10-21.

Winter, M.F. (1988). The culture and control of expertise. New York: Greenwood Press.

Witt, M. (2008). Institutional repositories and research data curation in a distributed environment. Library Trends, 57, 191-201.

Witz, A. (1992). Professions and patriarchy. London: Routledge.

Xia, J., Gilchrist, S.B., Smith, N.X.P., Kingery, J.A., Radecki, J.R., Wilhelm, M.L.,...Mahn, A.J. (2012). A review of open access self-archiving mandate policies. Portal: Libraries and the Academy, 12, 85102.

Xu, H., \& Chen, H. (1999). What do employers expect? The educating systems librarian research project report 1. The Electronic Library, 17, 171-179.

$\mathrm{Xu}, \mathrm{H} .$, \& Chen, H. (2000). Whom do employers actually hire? The educating systems librarian research project report 2. The Electronic Library, 18, 171-182.

$\mathrm{Xu}, \mathrm{H} ., \mathrm{\&}$ Chen, H. (2001). Can we meet the challenge? The educating systems librarian research project report 3. The Electronic Library, 19, 315-326. 